\title{
Distribution and abundance of avifauna on the foothills of Mt. Pangasugan, Baybay, Leyte, Philippines
}

\author{
Maritess B. Labrador and Teofanes A. Patindol \\ Department of Forest and Wildlife Management and Conservation, College of \\ Forestry and Natural Resources, Leyte State University, \\ Baybay, Leyte, Philippines
}

\section{ABSTRACT}

Labrador, M. B. and T. A. Patindol. 2006. Distribution and abundance of avifauna on the foothills of Mt. Pangasugan, Baybay, Leyte. Ann. Trop. Res. 28(2):111-128.

This study determined the distribution and abundance of avifauna on the foothills of Mount Pangasugan using the standard transect method. A total of 46 avifaunal species belonging to 12 orders and 27 families with $24 \%$ endemism were found in the three selected sites based on habitat types, degree of disturbance and elevation range. Most represented order is Passeriformes while the most represented family is Columbidae.

Patterns of distribution and abundance of avifauna tend to be associatedwith habitat type and degree of disturbance. The most abundant and most frequently encountered species are the generalists, which can tolerate various degree of disturbance in a wide range of habitats; the least frequently occurring and least abundant species are mostly endemic interior species which prefer relatively intact forest at higher elevations where disturbance is very minimal. These specialist groups of avifaunal species, which are mostly internationally recognized as threatened, show unique association with particular habitat type, thus considered to be highly sensitive to habitat change. Protection of the remaining forests in Mount Pangasugan is deemed necessary for the survival of these interior species.

Keywords: avifauna, distribution and abundance, Mt. Pangasugan 


\section{INTRODUCTION}

The Philippines is endowed with a rich and abundant bird life. Gonzales and Rees (1988) reported that there are some 557 bird species known to the Philippines and about 300-500 subspecies, 104 species are seasonal visitors or passage migrants and there are strugglers or irregular visitors. Of the estimated 160 or more species, 66 are known to occur only on one island.

Many species of birds in the Philippines, however, are threatened with extinction owing to the loss and destruction of habitat (Fisher and Hicks, 2000). One of the most notable birds under threat is the Philippine Eagle (Pithecophaga jefferyi), which may be down to a population of between 200 and 300 birds, because of loss of extensive forest cover. Other notable species that suffer the same fate as a result of habitat fragmentation are the 2 island endemics of Cebu namely: Cebu Black Shama (Copsychus cebuensis) and Cebu Flowerpecker (Dicaeum quadricolor). The pressure on the birds from loss of habitat continues practically unabated today mainly as a result of the continuous demand for land for agriculture.

Many birds in the Philippines are also subject to intensive hunting pressure for their meat and for the pet trade (Fisher and Hicks, 2000). Large pigeons and hornbills are highly attractive to hunters for their meat. Parrots are commonly trapped for the pet trade most notably the Philippine Cockatoo (Cacatua haematuropygia). Its conservation status is now elevated to "critically endangered" due to intense pressure from the highly attractive international pet trade.

Mt. Pangasugan, specifically its lower slopes facing Camotes Sea, undoubtedly has undergone a massive habitat transformation through the years due to establishment of settlements, experimental sites and agricultural expansion, among others. At present, there has been no study conducted pertaining to the distribution and abundance of avifauna in Mt. Pangasugan. Although there was a bird expedition conducted by the group of Mallari in 1987 (Mallari et al., 2001), little information is available on their status. The study provides information on the status of avian species found in the area, which is essential in the formulation of conservation measures before these species would become seriously threatened. In addition to the little information on avifauna, the information would form part of the database reflective of the total biological diversity resources of Mt. Pangasugan. 


\section{MATERIALS AND METHODS}

\section{Study area}

Mt.Pangasugan, with an elevation of about $1,150 \mathrm{~m}$ above sea level, is one of the peaks of the Central Cordillera of Leyte. It lies at the western boundaries of an area of primary forest that is about $150 \mathrm{~km}^{2}$ more in extent (Hearney et al., 1989). It is situated north $\left(10^{\circ} 44^{\prime} \mathrm{N} / 124^{\circ} 48^{\prime} \mathrm{E}\right)$ of the western coastal town of Baybay, Leyte. At its foot lies the main campus of Leyte State University, formerly ViSCA. The western side of the mountain is composed of parallel ridges which descend gradually to the narrow alluvial plane. The northem and southern sides of the ridges are generally steep giving rise to the young rivers like Pangasugan, Lago-lago and Calbiga-a Rivers. Its geology is dominated by andesite and basaltic pyroclastics ranging in age from the Pliocene to recent. They commonly occur as volcanic agglomerates and pyroclastic breccia referred to as Pangasugan formation. It lies west of the Philippine fault line that passes approximately along the center of Leyte (Asio, 1994).

The climate belongs to Type IV classification, which is characterized by more or less uniform distribution of rainfall throughout the year. The mean annual rainfall is $2,700 \mathrm{~mm}$. Heavy rains come in November to January (Coronas, 1920).

\section{Sampling sites}

Sampling was done in three sites, which cover different habitat types, disturbance level and elevation. Sampling Site 1 was located in the lower campus of Leyte State University (an alluvial plane) extending from the beach to the Molave Hill and shows severe disturbance. The sampling site cuts across residential and academic and research complexes, experimental plots and agricultural production areas. The elevation ranges from sea level up to about 50 meters above sea level ( $\mathrm{m}$ asl). Sampling Site 2 was located along the Calbiga-a River specifically from the Waterwheel complex at the front of the ridge to a elevation of about $200 \mathrm{~m}$ asl. The river cuts across several habitat types such as abaca (Ḿusa textilis) and coconut (Cocos nucifera) plantations and experimental plots, regeneration and secondary forest. Sampling Site 3 was located along Cantubias Ridge from the College of Forestry and Natural 
Resources complex to an elevation of about $300 \mathrm{~m}$ asl. The different habitat types found in the latter site include grasslands, tree plantations of both native and exotic species, shifting cultivation farms, abaca and coconut plantations, early and late regeneration areas and secondary forests.

\section{Avifaunal survey}

Composition and distribution of avian species were assessed using the transect survey method based on the Haribon Guidelines for Bird Surveys (Haribon Foundation, undated). A transect line measuring $2 \mathrm{~km}$ was set in every sampling site. Markers were established at every $250 \mathrm{~m}$ serving as observation stations along the transect line. The transect was walked at the speed of 15 minutes for each $250 \mathrm{~m}$ of the route. The avifaunal inventory was conducted early mornings (from 6:00 to 9:00 A.M.) and late afternoons (from 3:00 to 6:00 P.M.) for a total of three days which is equivalent to 18 hours of observation per transect. All species of birds encountered along the transect were recorded. For each species seen or heard, the following information were noted: species name, number of individuals, and habitat types. Identification was up to the species level whenever possible. Nomenclature and classification were based on Fisher and Hicks (2000), Kennedy et al.(2000), and Dupont (1971).

Relative abundance was based on the categories described by Diesmos and Mallari (1996) as cited by Ticsay and Ledesma (1998) and is presented in Table 1.

\section{Data computation and analysis}

Degrees of similarity between sites were determined using Sorensen's Index of Similarity (Magurran, 1988) as follows:

$$
\begin{aligned}
\mathrm{SI}= & \begin{array}{l}
2 c \\
-a+b
\end{array} \\
\text { where: } \mathrm{S} & =\text { Sorensen's Coefficient } \\
\mathrm{a} & =\text { number of species in one site } \\
\mathrm{b} & =\text { number of species in the other site } \\
\mathrm{c} & =\text { number of species common to both sites }
\end{aligned}
$$


Species richness for each sampling site was measured using the Menhinick's Richness Index (Magurran, 1998) with the following equation:

$$
\mathrm{R} 2=\mathrm{S} / \mathrm{n}
$$

where: $\mathrm{S}=$ total number of species observed

$\mathrm{n}=$ total number of individuals observed

Species diversity for each sampling site was computed using Shannon's Diversity Index (Magurran, 1988) with the formula:

$$
\mathrm{H}^{1}=\Sigma \mathrm{p}_{\mathrm{i}} 1 \mathrm{n} \mathrm{p}_{\mathrm{i}}
$$

where: $\mathrm{H}^{1}=$ Shannon-Weaver Index (also called Shannon-Wiener)

$\mathrm{S}=$ number of species

$\mathrm{P}=$ proportion of individuals on the baundance of the ith expressed as proportion of the total abundance

$\ln =\log$ base $n$

Index of Dominance was computed using Simpson's Index (Magurran, 1988) using the equation:

$$
\mathrm{D}=\left[\mathrm{n}_{1}\left(\mathrm{n}_{1}-1\right) / \mathrm{N}(\mathrm{N}-1)\right]
$$

where: $n_{1}=$ number of individuals in the ith species

$\mathrm{N}=$ total number of individuals

Evenness Index was also determined using the following equation:

$$
\text { Es }=H^{1 / \text { in } S}
$$

where: $\mathrm{H}^{\mathrm{I}}=$ Shannon Index of Diversity

$$
\mathrm{S}=\text { number of species }
$$


Table 1. Relative abundance categories*

\begin{tabular}{ll}
\hline CAJEGORY & \multicolumn{1}{c}{ DESCRIPTION } \\
\hline Common & $\begin{array}{l}\text { Recorded during the whole duration of observation } \\
\text { with more than } 50 \text { individuals }\end{array}$ \\
Uncommon & $\begin{array}{l}\text { Recorded more than } 5 \text { times with less than } 15 \\
\text { individuals }\end{array}$ \\
Rare & Recorded less than 5 times with one or two individuals \\
Scarce & Recorded with only one individual \\
Rare-uncommon & Recorded as either rare or common \\
\hline
\end{tabular}

*Based on Diesmos and Mallari (1996)

Table 2. Avian taxa recorded on the foothills of Mt. Pangasugan, c. 2005.






\begin{tabular}{|c|c|c|c|c|}
\hline & & Halcyon chloris & White-collard Kingfisher & $\mathrm{H} \& \mathrm{~S}$ \\
\hline & Meropidae & Merops viridis & Bhue-throated Bee-eater & $H \& S$ \\
\hline \multirow[t]{2}{*}{ Cuculiformes } & Cuculidae & Centropus viridis* & Philippine Coucal & $\mathrm{H} \& \mathrm{~S}$ \\
\hline & & Eudynamys scolopacea & Common Koel & Heard \\
\hline Falconiformes & Accipitridae & Haliastur indus & Brahminy Kite & $\mathrm{H} \& \mathrm{~S}$ \\
\hline Galliformes & Phasianidae & Gallus gallus & Red Jungle Fowl & Heard \\
\hline \multirow[t]{3}{*}{ Gruiformes } & Rallidae & Amaurornis phoenicurus & White-breasted Waterhen & $\mathrm{H} \& \mathrm{~S}$ \\
\hline & & Gallinula chloropus & Common Moorhen & $\mathrm{H} \& \mathrm{~S}$ \\
\hline & & Gallirallus torquatos & Barred Rail & $\mathrm{H} \& \mathrm{~S}$ \\
\hline \multirow[t]{18}{*}{ Passeriformes } & Artamindae & Artamus leocorynchus & $\begin{array}{l}\text { White-breasted } \\
\text { Woodswallow }\end{array}$ & Seen \\
\hline & Corvidae & Corvus macrorhynchos & Large-billed Crow & $\mathrm{H} \& \mathrm{~S}$ \\
\hline & & Lalaga nigra & Pied Thriller & Seen \\
\hline & Estrildidae & Lonchura mallaca & Chestnut Munia & $\mathrm{H} \& \mathrm{~S}$ \\
\hline & Laniidae & Lanius cristatus & Brown Shrike & Seen \\
\hline & Muscicapidae & Rhipidura javanica & Pied Fantail & $\mathrm{H} \& \mathrm{~S}$ \\
\hline & Nectariniidae & Nectarinia jugularis & Olive-backed Sunbird & $\mathrm{H} \& \mathrm{~S}$ \\
\hline & & Nectarinia sperata & Purple-throated Sunbird & $\mathrm{H} \& \mathrm{~S}$ \\
\hline & Oriolidae & Oriolus chinensis & Black-naped Oriole & $\mathrm{H} \& \mathrm{~S}$ \\
\hline & Passeridae & Motacilla flava & Yellow Wagtail & Seen \\
\hline & Ploceidae & Passer montanus & Eurasian Sparrow & $\mathrm{H} \& \mathrm{~S}$ \\
\hline & Pycnonotidae & Hypsipetes philippinus* & Philippine Bulbul & $\mathrm{H} \& \mathrm{~S}$ \\
\hline & & Pycnonotus goiavier & Yellow-vented Bulbul & $\mathrm{H} \& \mathrm{~S}$ \\
\hline & Sturnidae & Sarcops calvus & Coleto & $\mathrm{H} \& \mathrm{~S}$ \\
\hline & & Aplonis panayensis & Asian Glossy Starling & $\mathrm{H} \& \mathrm{~S}$ \\
\hline & Sylviidae & Megalurus palustris & $\begin{array}{l}\text { Striated Canegrass } \\
\text { Warbler }\end{array}$ & Seen \\
\hline & & $\begin{array}{l}\text { Orthothomus } \\
\text { castaneiceps* }\end{array}$ & Philippine Tailorbird & Seen \\
\hline & Turdidae & Copsychus saularis & Oriental Magpie Robin & Seen \\
\hline \multirow[t]{2}{*}{ Piciformes } & Picidae & Dryocopus javanensis & $\begin{array}{l}\text { White-bellied } \\
\text { Woodpecker }\end{array}$ & Seen \\
\hline & & $\begin{array}{l}\text { Megalaima } \\
\text { haemacephala }\end{array}$ & Coppersmith Barbet & Heard \\
\hline \multirow[t]{2}{*}{ Psittaciformes } & Psittacidae & $\begin{array}{l}\text { Loriculus philippensis* } \\
\text { Prioniturus discurus* }\end{array}$ & $\begin{array}{l}\text { Colasisi } \\
\text { Rlue_rowned Racket-tail }\end{array}$ & $\begin{array}{l}\text { Seen } \\
\text { Seen }\end{array}$ \\
\hline & & Prionitu & Bluexcrowiled Na & \\
\hline
\end{tabular}

*Philippine endemic; ${ }^{* *}$ Greater Mindanao faunal region endemic

***BASIS $=$ Basis of identification; $\mathrm{H} \& \mathrm{~S}=$ Heard and Seen 


\section{RESULTS AND DISCUSSION}

\section{Species composition}

A total of 46 avian species was recorded in the three sampling sites primarily based on transect survey results (Table 2). These species belong to 12 orders with 27 families. Order Passeriformes was the most represented with 19 species belonging to 14 families. The next most represented order was Columbiformes with 9 species belonging to 2 families. This was followed by orders Coraciiformes and Gruiformes with 4 and 3 species, respectively. The least represented orders were Apodiformes, Caprimulgiformes, Cloniformes, Falconiformes and Galliformes with only 1 species each.

The most represented family was the Columbidae with 6 species of dive and one species of pigeon. It was followed by families Alcedinidae and Rallidae with 3 species of kingfisher and 3 species of wading birds, respectively. Most species belonging to Columbidae family encountered during the survey were associated with both open and partly disturbed areas. They feed on variety of small fruits and berries wherein they disperse the seeds. This ability is vital for ecological functions in the natural environment particularly in regeneration of forest ecosystem.

Alcedinidae species are mostly adapted to water habitats and are mostly piscivores and also feed on crustaceans and amphibians (Ticsay and Ledesma, 1988). The remaining water habitats provide an excellent habitat and food source for this group of birds. Rallidae species are commonly associated with swamp or marsh habitat and undergrowth in coconut plantations and early regeneration areas.

Of the species recorded, $11(23.91 \%)$ species are endemic to the Philippines. Only one species, the Silvery Kingfisher (Alcedo argentata) is endemic to the Greater Mindanao Faunal Region and Leyte province.

\section{Species distribution}

The distribution of bird species in the three sampling sites is shown in Table 3. Site 3 had the highest number of species observed with a total of 39 species, followed by Site 2 with 37 species. Site 1 had the lowest number 
Table 3. Distribution of avian taxa recorded on the foothills of Mt. Pangasugan, c. 2005.

SCIENTIFIC NAME

Alcedo argentata**

Amaurornis phoenicurus

Aplonis panayensis

Artamus leocorynchus

Bubulus ibis

Buceros hydrocorax*

Caprimulgus manillensis

Centropus viridis*

Chalcophalps indica

Collocalia troglodytes*

Copsychus saularis

Corvus macrorhynchos

Dryocopus javanensis

Eudynamys scolopacea

Gallinula chloropus

Gallirallus torquatos

Gallus gallus

Geopelia straita

Halcyon chloris

Halcyon smyrnensis

Haliastur Indus

Hypsipetes philippinus*

Lalaga nigra

Lanius cristatus

Lonchura mallaca

Loriculus philippensis*

Macronous striaticeps

Macropygia phasianella Reddish Cuckoo Dove

Megalaima haemacephalaCoppersmith Barbet

Megalurus palustris

Merops viridis

Motacilla flava

Nectarinia jugularis

Nectarinia sperata

Oriolus chinensis

Orthothomus castaneiceps*

Passer montanus
Silvery Kingfisher

\section{COMMON NAME}

White-breasted Waterhen

Asian Glossy Starling

White-breasted

Woodswallow

Cattle Egret

Rufous Hornbill

Philippine Nightjar

Philippine Coucal

Common Emerald Dove

Pygmy Swiftlet

Oriental Magpie Robin

Large-billed Crow

White-bellied Woodpecker

Common Koel

Common Moorhen

Barred Rail

Red Jungle Fowl

Zebra Dove

White-collard Kingfisher

White-throated Kingfisher

Brahminy Kite

Philippine Bulbul

Pied Thriller

Brown Shrike

Chestnut Munia

Colasisi

Brown Tit-babbler

Striated Canegrass Warblerx

Blue-throated Bee-eater

Yellow Wagtail

Olive-backed Sunbird

Purple-throated Sunbird

Black-naped Oriole

*Philippine Tailorbird

Eurasian Sparrow
SAMPLINGSITES

1

23

$\mathrm{x}$

$\mathrm{x}$

$\mathrm{x}$

$\mathrm{x}$

$\mathrm{x}$

$\mathrm{x}$

$\mathrm{X}$

$\mathrm{X}$

$\mathrm{x}$

$\mathrm{x}$

$x$

$\mathrm{x}$

$\mathrm{x}$

$\mathrm{x}$

$\mathrm{x}$

$\mathrm{x}$

$x \quad x$

$\mathrm{x}$

$\mathrm{x}$

$\mathrm{x}$

$\mathrm{x}$

$\mathrm{x}$

$\mathrm{x}$

$\mathrm{x}$

$\mathrm{x}$

$\mathrm{x}$

$\mathrm{x}$

$\mathrm{x}$

$\mathrm{x}$

$\mathrm{x}$

$\mathrm{x}$

$\mathrm{x}$

$\mathrm{x}$

$\begin{array}{ll}x & x \\ x & x\end{array}$

$x$

$\mathrm{x}$

$\mathrm{x}$

$\mathrm{x}$

$\mathrm{x}$

$\mathrm{X}$

$\mathrm{x} \quad \mathrm{x}$

$\mathrm{x}$

$\mathrm{x}$

$\mathrm{x}$.

$\mathrm{x}$

$\mathrm{x}$

$\mathrm{x}$

$\mathrm{x}$

$\mathrm{x}$

$\mathrm{x}$

$\mathrm{x}$

$\mathrm{x}$

$\mathrm{x}$

$\mathrm{x} \quad \mathrm{x}$

x $\mathrm{x}$

$\begin{array}{ll}x & x\end{array}$

$\mathrm{x} \quad \mathrm{x}$

$x \quad x$

x $\quad x$

$\mathrm{x} \quad \mathrm{x}$

$\mathrm{X}$

$\mathrm{x}$

x$$
x
$$

$\mathrm{x}$

$x \quad x$

$\mathrm{x}$

$x$

$x$

X 
Table 3. Continuation

Penelopides panini* Tariktik Hombill

Phapitreron amethystina* Amethyst Brown

$\mathbf{x} \quad \mathbf{x}$

Phapitreron leucotis*

White-eared Brown

x $\quad \mathrm{x} \quad \mathrm{x}$

Prioniturus discurus

Fruit Dove

Pycnonotus goiavier

Blue-crowned Racket-tail

$\begin{array}{rrr} & \mathrm{x} & \mathrm{x} \\ \mathrm{x} & \mathrm{x} & \mathrm{x} \\ \mathrm{x} & \mathrm{x} & \mathrm{x} \\ \mathrm{x} & \mathrm{x} & \mathrm{x} \\ \mathrm{x} & \mathrm{x} & \mathrm{x} \\ & \mathrm{x} & \mathrm{x}\end{array}$

Rhipidura javanica

Sarcops calvus

Yellow-vented Bulbul

Pied Fantail

Coleto

Streptopelia chinensis

Treron pompadora

Spotted Dove

Pompadour Green Pigeon

Total

*Philippine endemic; ** Greater Mindanao faunal region endemic; $x=$ present Site 1=Lower campus; Site 2=Calbigaa River; Site 3=Cantubias Ridge

with 33 species. The difference in the number of species among the 3 sites could be due to habitat variability. The relatively high number of species in Site 3 could be due to the highly heterogeneous habitat types present which range from cultivated areas to regeneration to second growth forest. The low number of species in the 2 other sites on the other hand, could be due to more or less homogenous habitat. Site 1 represents a homogenous disturbed area while Site 2 is a predominantly riparian community, the adjacent areas of which are under active cultivations and regeneration.

A total of 25 species were observed to be common to the three sites; 7 species to Site 2 and 3; 4 species to Site 1 and 3; and only 1 species to Site 1 and 2. Few species showed limited distribution or restricted range. Three species were restricted only to Site 1 and the same number to Site 2 . Only 2 species were observed present only in Site 3.

The three species observed only in Site 1 included Asian Glossy Starling (Aplonis panayensis), White-throated Kingfisher (Halcyon smyrnensis) and Eurasian Sparrow (Passer montanus). These species are generally known to occur in disturbed areas. Asian Glossy Starling was observed near the Molave Hill where there is a mixture of indigenous and exotic trees growing.

White-throated Kingfisher was observed along natural water courses 
and near bodies of waterbordering rice paddies. Eurasian Sparrow was observed in areas activley cultivated for rice. This cosmopolitan species has been associated with settlements and is considered a serious pest of rice (Asid, 2005). These two species were commonly observed in the rice paddies betwen LSU Mall and LSU Gym.

White -breasted Waterhen (Amaurornis phoenicurus) Philippine Nightjar (Caprimulgus manillensis), and Reddish Cuckoo Dove ( Macropygia phasianella) were observed only in Site 2 . These species were observed in the second growth forests along Calbigaa River at relatively higher elevations. White -breasted Waterhen was present in the dense undergrowth close to the river bank.

Philippine Tailorbird (Orthothomus castaneiceps) and Amethyst Brown Fruit Dove (Phapitreron amethystina) were observed only Site 3. The Philippine Tailorbird was observed in abandoned cultivation under coconut plantation. The dense understory provides suitable microhabitat for this species being insectivorous. The Amethyst Brown Fruit Dove was frequently observed at the border between cultivation and second growth forests and even near coconut plantations where the White-eared Brown Fruit Dove was frequently observed, too. These species were edge species that feed on fruits which are abundant in edges between cultivation and forests or under coconut plantation where regeneration of the understory allows the growth of fruit-bearing tree species (Ticsay and Ledesma, 1998).

Few species had shown altitudinal and habitat preferences. They include the Rufous Hornbill (Bocerus hydrocorax), Tariktik Hornbill (Penelopides panini), Blue-crowned Racket-tail (Prioniturus discurus) Pompadour Green Pigeon (Treron pompadora) and Silvery Kingfisher (Alcedo argentata). These were recorded in a secondary forest at higher elevation along Calbiga-a River and Cantubias Ridge.

\section{Relative abundance}

Twenty-five species were considered common which means more than 50 individuals were recorded during the entire observation period (Table 4). Nine species were classified as "Uncommon" having occurred more than 5 times but numbering less than 50 individuals. The same number is considered 
Table 4. Relative abundance of avian taxa recorded on the foothills of Mt. Pangasugan, c. 2005.

\begin{tabular}{|c|c|c|c|}
\hline SCIENTTFIC NAME & COMMON NAME & NUMBER & RELATIVEABUNDANCE \\
\hline Hypsipetes philippinus* & Philippine Bulbul & 762 & Common \\
\hline Lonchura mallaca & Chestnut Munia & 670 & Common \\
\hline Nectarinia jugularis & Olive-backed Sunbird & 549 & Common \\
\hline Artamus leocorynchus & $\begin{array}{l}\text { White-breasted } \\
\text { Woodswallow }\end{array}$ & & \\
\hline \multirow[t]{2}{*}{ Phapitreron leucotis* } & White-eared Brown & 535 & Common \\
\hline & Fruit Dove & 445 & Common \\
\hline Nectarinia sperata & Purple-throated Sunbird & 350 & Common \\
\hline Passer montanus & Eurasian Sparrow & 259 & Common \\
\hline Loriculus philippensis* & Colasisi & 210 & Common \\
\hline Pycnonotus goiavier & Yellow-vented Bulbul & 181 & Common \\
\hline Geopelia straita & Zebra Dove & 174 & Common \\
\hline Copsychus saularis & Oriental Magpie Robin & 165 & Common \\
\hline Oriolus chinensis & Black-naped Oriole & 157 & Common \\
\hline Eudynamys scolopacea & Common Koel & 126 & Common \\
\hline Bubulus ibis & Cattle Egret & 111 & Common \\
\hline Halcyon chloris & White-collard Kingfisher & 107 & Common \\
\hline Lanius cristatus & Brown Shrike & 101 & Common \\
\hline Collocalia troglodytes* & Pygmy Swiftlet & 94 & Common \\
\hline Macronous striaticeps & Brown Tit-babbler & 87 & Common \\
\hline \multicolumn{2}{|c|}{ Megalaima haemacephalaCoppersmith Barbet } & 87 & Common \\
\hline Centropus viridis* & Philippine Couca 1 & 85 & Common \\
\hline Sarcops calvus & Coleto & 84 & Common \\
\hline Lalaga nigra & Pied Thriller & 80 & Common \\
\hline Motacilla flava & Yellow Wagtail & 80 & Common \\
\hline Rhipidura javanica & Pied Fantail & 78 & Common \\
\hline Penelopides panini* & Tariktik Hornbill & 73 & Common \\
\hline Merops viridis & Blue-throated Bee-eater & 46 & Uncommon \\
\hline Streptopelia chinensis & Spotted Dove & 42 & Uncommon \\
\hline \multirow[t]{2}{*}{ Megalurus palustris } & Striated Canegrass & & \\
\hline & Warbler & 37 & Uncommon \\
\hline Gallinula chloropus & Common Moorhen & 33 & Uncommon \\
\hline Gallirallus torquatos & Barred Rail & 32 & Uncommon \\
\hline \multicolumn{4}{|c|}{ Phapitreron amethystina*Amethyst Brown } \\
\hline & Fruit Dove & 31 & Uncommon \\
\hline Aplonis panayensis & Asian Glossy Starling & 30 & Uncommon \\
\hline Haliastur Indus & Brahminy Kite & 24 & Uncommon \\
\hline Alcedo argentata** & Silvery Kingfisher & 18 & Uncommon \\
\hline
\end{tabular}




\begin{tabular}{|c|c|c|c|}
\hline Chalcophalps indica & Common Emerald Dove & 16 & Uncommon \\
\hline Treron pompadora & Pompadour Green Pigeon & 14 & Rare-uncommon \\
\hline Buceros hydrocorax * & Rufous Hornbill & 14 & Rare-uncommon \\
\hline Amaurornis phoenicurus & White-breasted Waterhen & 12 & Rare-uncommon \\
\hline $\begin{array}{l}\text { Orthothomus } \\
\text { castaneiceps* }\end{array}$ & Philippine Tailorbird & 7 & Rare \\
\hline Halcyon smyrnensis & White-throated Kingfisher & 6 & Rare \\
\hline Gallus gallus & Red Jungle Fowl & 5 & Rare \\
\hline Dryocopus javanensis & White-bellied & & \\
\hline Prioniturus discurus & $\begin{array}{l}\text { Woodpecker } \\
\text { Blue-crowned Racket-tail }\end{array}$ & 4 & $\begin{array}{l}\text { Kare } \\
\text { Rare }\end{array}$ \\
\hline Corvus macrorhynchos & Large-billed Crow & 3 & Rare \\
\hline Caprimulgus manillensis & Philippine Nightjar & 2 & Rare \\
\hline Macropygia phasianella & Reddish Cuckoo Dove & 2 & Rare \\
\hline
\end{tabular}

*Philippine endemic; ** Greater Mindanao faunal region endemic.

rare for having occurred less than 5 times and with one or two individuals for every encounter.

Most abundant species were the Philippine Bulbul (Hypsipetes philippinus), Chestnut Munia (Lonchura mallaca) and Olive-backed Sunbird (Nectarinia jugularis) The bulbuls and sunbirds are either frugivorous, nectivorous, or insectivorous or both (Ticsay and Ledesma, 1998). The presence of dense undergrowth in regeneration areas which harbor high insect population and the availability of fruit-bearing (mostly pioneer) tree species across the three sites warrant the steady supply of food for these group of bird species. The manikins and sparrows, which are both insectivorous and grain feeders, are cosmopolitan species hence adapted to the disturbed condition in agricultural areas and human settlements.

Among the species observed as common, 2 are considered threatened. These are the Colasisi (Loriculus philippensis) and Tariktik Hornbill (Penelopides panini). Colasisi, an endemic species that has been widely sought by traders for the pet trade, is now considered threatened due to continuous and unregulated hunting or capture. Tariktik Hornbills were still abundant along second growth forest in Cantubias Ridge and Calbiga-a River which are usually situated at higher elevations. The Colasisi is a lowland forest species but was observed also in partly disturbed areas of Cantubias Ridge and Calbiga-a 
River where it fed on fruits, berries, nectar or pollen.

Three species to include the Pompadour Green Pigeon (Treron pompadora) Rufous Hombill (Buceros hydrocorax) and White-breasted Waterhen (Amaurornis phoenicurus) were recorded as Rare-Uncommon. These are all interior species associated with intact forests for cover. These species are also game species owing to their big body mass. Pompadour Green Pigeon and Tariktik Hornbill are both secretive interior species but frequently seen in partly open areas to feed on fruits. White-breasted Waterhen are common in edges bordering forests and grasslands near bodies of water.

Eight species were recorded as rare, namely: Philippine Tailorbird (Orthothomus castaneiceps), White-throated Kingfisher (Halcyon smyrnensis) Red Jungle Fowl (Gallus gallus), White-bellied Woodpecker (Dryocopus javanensis), Blue-crowned Racket-tail (Prioniturus discurus), Large-billed Crow (Corvus macrorhynchos), Philippine Nightjar (Caprimulgus manillensis) and Reddish Cuckoo Dove (Macropygia phasianella). Except for the Large-billed Crow, which is adapted to open areas, all species are forest and edge species, thus need a forest entirely, or as part of their habitat requirement particularly for cover and survival

Species recorded as "Uncommon" and "Rare" species are fully or partly dependent on forests for survival, thus this call for the protection of the remaining forests on the foothills of Mt. Pangasugan to cater to the habitat and cover requirement of these species. Some of the species are also associated with specialized habitat like bodies of water. Aside from this, since most rare species are game species, immediate protection of these species is highly recommended. This can be in the form of complete ban on hunting and dissemination of information campaign materials to the local inhabitants surrounding the foothills of Mt. Pangasugan for the conservation of these species.

\section{Degree of similarity}

Comparison of th especies composition of th ethree sites using Sorensen's Coefficient in Table 5 showed high degree of similarity between sites. Sites 2 and 3 had the highest index of similarity of $85.52 \%$. They were followed by Sites 1 and 3 and Sites 1 and 2 with $81.69 \%$ and $75.36 \%$, respectively.

The relatively high similarity between sites could be explained in terms of habitat type combination. Sites 2 and 3 had the highest similarity index since 
Table 5. Avifaunal similarity indices (Sorensen's coefficient) of the three study sites on the foothills of Mt. Pangasugan, c. 2005

\begin{tabular}{llll} 
Study Site & \multicolumn{3}{c}{ Similarity Index $(\%)^{*}$} \\
\cline { 2 - 4 } & 1 & 2 & 3 \\
\hline 1 & 1 & 26 & 29 \\
2 & 75.36 & 1 & 33 \\
3 & 81.69 & 85.52 & 1 \\
\hline
\end{tabular}

* Values in shaded cell refer to the number of species common to both sides

Table 6. Species richness, diversity, dominance and evenness of the three study sites on the foothills of Mt. Pangasugan, c. 2005.

\begin{tabular}{lllllll}
\hline $\begin{array}{l}\text { Study } \\
\text { Sites }\end{array}$ & $\begin{array}{l}\text { No. of } \\
\text { Species }\end{array}$ & $\begin{array}{l}\text { No. of } \\
\text { Individuals }\end{array}$ & $\begin{array}{l}\text { Species } \\
\text { Richness }\end{array}$ & $\begin{array}{l}\text { Species } \\
\text { Diversity }\end{array}$ & $\begin{array}{l}\text { Index of } \\
\text { Dominance }\end{array}$ & $\begin{array}{l}\text { Index of } \\
\text { Evenness }\end{array}$ \\
\hline 1 & 33 & 2906 & 0.612 & 2.834 & 0.089 & 0.810 \\
2 & 37 & 1902 & 0.848 & 2.729 & 0.092 & 0.762 \\
3 & 39 & 1136 & 1.157 & 2.869 & 0.089 & 0.789 \\
Total & 46 & 5944 & 0.597 & 3.075 & 0.064 & 0.808 \\
\hline
\end{tabular}

these two sites are practically similar in terms of habitat type combination such as agricultural cultivation, patches of tree plantations, abacaand coconut plantations, regeneration areas and second growth forests. This combination of habitat types has high structural diversity that supports high availability of food for bird species. The relatively high similarity between Sites 1 and 3 can also be explained by the presence of disturbed habitat types such as abandoned cultivation and tree plantations which are common to both sites. Most likely the same habitat types harbor the same species of both birds considering that these two sites are not distant from each other.

Sites 1 and 2 were the least similar because their habitat types differed considerably with one another. Site 1 was relatively open thus it harbored species which were adapted to open sites. Site 2 vegetation cover was mainly 
of second growth and late regeneration forest which are favorite habitats of interior species.

The result indicates that a majority of the species are common to all the three sites. These species are usually adapted to a wide range of habitat types from highly disturbed sites in residential and office complexes and agricultural farms in the lower campus of Leyte State University to the less disturbed secondary forests at elevations of about $300 \mathrm{~m}$ asl. There are however, species that are most likely to be adversely affected by habitat transformation. This calls for the conduct of similar studies in areas on the foothills of Mt. Pangasugan not covered by the present study to determine other species that are uniquely associated with specialized habitat types. Species of limited range are the ones that easily succumb to the effect of habitat transformation thus should be prioritized in any conservation program.

\section{Species richness and diversity}

As shown in Table 6, Site 3 had the highest species richness of 1.127 with 1,136 individuals belonging to 39 species. Site 1 had the lowest species richness of 0.612 with 2,906 individuals belonging to 33 species. Looking at the composite value of the three sites, the species richness was relatively low at 0.5836 . This low value is due to the remarkably high number of individuals recorded in Site 1 that has great influence on the total number of individuals of the three sites.

Table 6 also shows that Site 3 had the highest species diversity at 2.869 . This is followed by Site 1 with 2.834. Surprisingly, these values are almost identical although the two sites varied significantly in terms of number of individuals. This is probably so because of the almost even distribution of individuals among species in Site 1 as reflected by the relatively high index of dominance which also relates inversely to species diversity.

The same trend was observed for the composite species diversity. It is highest compared to all three sites and had relatively high evenness value and low dominance value. This trend is indicative that the diversity value of the area may tend to increase with increasing sampling intensity as more new species may be encountered with increase in size of the total sampling area and observation period. This therefore suggests that similar studies be conducted in other areas not covered by the present study to account for more additional species. 


\section{CONCLUSION AND RECOMMENDATION}

Based on the results, the following conclusions and recommendations are drawn:

1. A total of 46 avifaunal species belonging to 12 orders with 27 families were recorded on the foothills of Mt. Pangasugan with about $24 \%$ endemism. Passeriformes was the most represented order while Columbidae was the most represented family.

2. The most abundant and most frequently encountered avifaunal species were associated with a wide range of habitats; the least frequently occurring and at the same time the least abundant species were the interior species which tend to specialize on relatively intact forest at higher elevations where disturbance is very minimal. It is therefore recommended that protection of the areas should immediately be undertaken. Protection should form part of an integrated conservation program that would address all other components of the biodiversity of Mt. Pangasugan.

3. There are positive indications that species richness and diversity tend to increase in the number of sampling sites because of the addition of new species to the total numberof species as number of sites is increased.

4. There are positive indications that some species tend to be uniquely associated with a particular site. Thus, it is highly recommended that more intensive bird surveys should be done on the foothills of Mt. Pangasugan to include other areas containing different habitat types in order to fully account for other important species that might have not been covered by the present study.

5. It is also recommended that another avifaunal survey be conducted during the dry months in order to account species that may be present or abundant only during the dry season.

\section{ACKNOWLEDGMENT}

The authors would like to thank Prof. Senona A. Cesar and Dr. Beatriz S. Belonias, of the Department of Biological Sciences, Leyte State University, for their suggestions and comments. Special thank is also extended to Richard Timola for the kind assistance during the field survey. 


\section{LITERATURE CITED}

ASID, R. 2005. Avifaunal Survey in the Wetlands of Leyte State University Campus. Unpublished B. S. Forestry Field Practice Manuscript. Leyte State University, Baybay, Leyte. 25 pp.

ASIO, V. B. 1994. The geology, geomorphology and soils of Leyte. In: Lecture Notes for the Southeast Asian Island Ecosystem Workshop \& Seminar, 4-15 April 1994, ViSCA, Baybay, Leyte pp.64-73.

CORONAS, J. 1920. Climate and Weather of the Philippines. Bureau of Printing. Manila. $189 \mathrm{pp}$.

DUPONT, J. E. 1971. Philippine Birds. Monograph Series No. 2. Delaware Museum of Natural History. Greenville, Delaware, USA. 139pp.

FISHER, T. and N. HICKS, 2000. Birds of the Philippines: A Photographic Guide. New Holland Publishers, Ltd. UK. 144pp.

GONZALES, P. C. and C. P. REES, 1988. Birds of the Philippines. Haribon Foundation for the Conservation of Natural Resources, Inc. Manila, Philippines. 184p.

HARIBON FOUNDATION, Undated. Guidelines for Bird Surveys. Quezon City, Philippines. 4pp.

HEANEY, L. R., P. D. HEIDEMANN, E. A. RICKARF, R. B. UTZWIRUM, and J. S. KLOMPEN, 1989. Elevational zonation of mammals in the Central Philippines. Tropical Ecology 5:259-280.

KENNEY, R.S., P.C. GONZALES, E.H. DICKINSON, H.C. MIRANDA Jr., and T.H. FISHER. 2000. A Guide to the Birds of the Philippines. Oxford University Press, Oxford New York. 369p.

MAGURRAN, A. 1988. Ecological Diversity and Its Measurement. Chapman and Hall. Princeton University. $179 \mathrm{pp}$.

MALLARI, N. A. D., B. R. TABARANZA and M. CROSBY. 2001. The Important Bird Areas in the Philippines. Haring Ibon. 485pp.

TICSAY, M. V. and M. M. LEDESMA. 1998. Faunal inventory of Naujan Lake Natural Park and its adjacent watershed, Oriental Mindoro, Philippine. Sylvatrop. Technical Journal of the Philippine Ecosystem and Natural Resources. 8 (1\&2); $62-78$. 